\title{
Cancer immunity and therapy using hyperthermia with immunotherapy, radiotherapy, chemotherapy, and surgery
}

\author{
Yohsuke Yagawa ${ }^{1,2}$, Keishi Tanigawa', Yasunobu Kobayashi', Masakazu Yamamoto ${ }^{2}$ \\ ${ }^{1}$ Bio-Thera Clinic, Tokyo 1600022, Japan. \\ ${ }^{2}$ Department of Surgery, Institute of Gastroenterology, Tokyo Women's Medical University, Tokyo 1628666, Japan.
}

Correspondence to: Dr. Keishi Tanigawa, Bio-Thera Clinic, 5-6-12 Shinjuku, Shinjuku-ku, Tokyo 1600022, Japan. E-mail: tanigawa@bio-c.jp

How to cite this article: Yagawa Y, Tanigawa K, Kobayashi Y, Yamamoto M. Cancer immunity and therapy using hyperthermia with immunotherapy, radiotherapy, chemotherapy, and surgery. J Cancer Metastasis Treat 2017;3:218-30.

\author{
Article history: \\ Received: 23 May 2017 \\ Accepted: 5 Jul 2017 \\ Published: 31 Oct 2017 \\ Key words: \\ Hyperthermia, \\ cancer immunity, \\ chemosensitizer, \\ radiosensitizer, \\ combination cancer therapy, \\ hyperthermic intraoperative \\ peritoneal chemotherapy
}

\begin{abstract}
Hyperthermia is a type of medical modality for cancer treatment using the biological effect of artificially induced heat. Even though the intrinsic effects of elevated body temperature in cancer tissues are poorly understood, increasing the temperature of the body has been recognized as a popular therapeutic method for tumorous lesions as well as infectious diseases since ancient times. Recently accumulated evidence has shown that hyperthermia amplifies immune responses in the body against cancer while decreasing the immune suppression and immune escape of cancer. It also shows that hyperthermia inhibits the repair of damaged cancer cells after chemotherapy or radiotherapy. These perceptions indicate that hyperthermia has potential for cancer therapy in conjunction with immunotherapy, chemotherapy, radiotherapy, and surgery. Paradoxically, the anticancer effect of hyperthermia alone has not yet been adequately exploited because deep heating techniques and devices to aggregate heat effects only in cancer tissues are difficult in practical terms. This review article focuses on the current understanding concerning cancer immunity and involvement of hyperthermia and the innate and adoptive immune system. The potential for combination therapy with hyperthermia and chemotherapy, radiotherapy, and surgery is also discussed.
\end{abstract}

\section{INTRODUCTION}

Cancer is one of the most fatal diseases in the world, inducing various conditions such as organ disorders from primary lesions or metastatic lesions and cachexia. Three standard therapeutic methods include surgery, chemotherapy, and radiotherapy; however, these are not satisfactory on the whole. Difficulties in treating cancer are due to its distinctive abilities for immune escape, metastasis, and tolerance to cancer therapies. These abilities result from the heterogeneity of cancer cells ${ }^{[1]}$ and the anticancer efficacy of conventional treatment methods has limitations. Recent progress has been made in cancer immunotherapy, a fourth cancer therapeutic method, including activated T-cell therapy and dendritic cell (DC) vaccines; however,

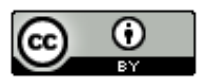

This is an open access article licensed under the terms of Creative Commons Attribution 4.0 International License (https://creativecommons.org/licenses/by/4.0/), which permits unrestricted use, distribution, and reproduction in any medium, as long as the original author is credited and the new creations are licensed under the identical terms.

For reprints contact: service@oaepublish.com

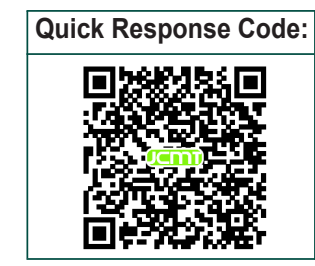


their therapeutic efficacy is still limited ${ }^{[2,3]}$. The more recent discovery of immune check-point inhibitors has demonstrated sensational long-term benefits in patients with advanced cancer and has highlighted the importance of immune responses to cancer, but its efficacy has been recognized only in a minority of patients ${ }^{[4,5]}$. Hence, current therapeutic methods need to be improved or new therapeutic cancer therapy developed for single or combination use. Recently, many reports have shown that an appropriate heat effect has potential anticancer efficacy and can enhance the efficacy of other cancer therapies. Nonetheless, fever itself is a complex physiological response ${ }^{[6]}$, with the intrinsic effects of elevated body temperature regarded as an important defense system for the body by increasing the immune reaction not only against infectious disease but also against cancer.

\section{Hyperthermia}

Even though the efficacy of intrinsic effects of elevated body temperature in tissues to cells is still being studied, it has been disclosed that the survival rate of cells is reduced by heating at $39-42{ }^{\circ} \mathrm{C}$, and it is amplified remarkably by heating at $\geq 42.5^{\circ} \mathrm{C}$ for $\geq 1 \mathrm{~h}$. There is no variation in tolerance between tissue types ${ }^{[7,8]}$. Hyperthermia is a type of cancer treatment using this feature to target cancer cells and their surrounding environment ${ }^{[9]}$. In the early days, hyperthermia alone at $42-44{ }^{\circ} \mathrm{C}$ was performed against recurrent tumors derived from head and neck cancer and breast cancer, which appeared on the surface of the body. The objective antitumor response in this set of superficial tumors was around $40 \%{ }^{[10-12]}$. However, most cancers, including primary sites as well as recurrent or metastatic sites, are located deep inside the body. This makes hyperthermia alone less effective because it is quite difficult to heat only cancer tissues to more than $42^{\circ} \mathrm{C}$ using currently available heating devices. Recently, the usefulness of mild hyperthermia with $39-42{ }^{\circ} \mathrm{C}$ (feverrange hyperthermia) for 1-2 $\mathrm{h}$ has been reported for combination use with other cancer therapies ${ }^{[13]}$. This method takes advantage of the difference in sensitivity to heat stress between normal tissues and cancerous tissues. The logic behind its use is that normal tissues have enough vascular distribution to drain the congestion of fever and avoid tissue damage in these shorter time periods. In contrast, in cancerous tissues, fever and heat stress tend to accumulate. Consequently, an anticancer effect can be obtained within the fever range while normal tissues endure ${ }^{[14]}$. Nevertheless, irradiation for a long period with a higher temperature than body temperature until cancer is eliminated is still harmful to normal tissues and homeostasis of the body.

In widespread use, the term hyperthermia generally includes regional hyperthermia, whole-body hyperthermia, and hyperthermic intraperitoneal chemotherapy (HIPEC). Ablation therapy, which uses microwave or a laser at $80-100{ }^{\circ} \mathrm{C}$, leading to direct cancer cell death by heat denaturation of proteins or necrosis ${ }^{[15]}$, may also be categorized as hyperthermia in the broad sense. Regional hyperthermia is a less invasive method of thermal therapy. In this method, heat effects are limited to the range of irradiation and have an expected role as a chemosensitizer or radiosensitizer used to augment the efficacy of chemotherapy or radiotherapy in situ[i]. The currently popular method for hyperthermia in clinical practice is mild hyperthermia applied to the regional cancer area by using an $8 \mathrm{MHz}^{[16,17]}$ or 13.56 $\mathrm{MHz}^{[18]}$ radiofrequency capacitive heating device, applied to the surface of the body directly above the cancer. In contrast, whole body hyperthermia heats areas of body and increases the systemic body temperature of patients ${ }^{[19]}$. This method is suitable for patients with metastases in multiple organs, including carcinomatosis. Increased effects of immune cells such as T cells and DCs located in the peripheral organs or circulation are also expected, in addition to the effect of regional hyperthermia ${ }^{[20]}$.

\section{T-cell-based immune responses to cancer}

T-cells are key immune cells with regard to specific immune responses against cancer. The pivotal events involved in the induction of successful T-cell mediated immune responses and those in the immune effector phase are shown in Figure 1. DCs are the major antigen-presenting cells (APCs), which are capable of initiating T-cell mediated immune response ${ }^{[21]}$. These cells usually reside in the epidermis of the skin and mucosal tissues to prepare to combat foreign enemies. This includes cancer antigens, which are fragments of tumor cells generated as a consequence of natural death or the interaction of tumors and innate immune cells such like natural killer (NK) cells ${ }^{[22,23]}$. DCs process and present these fragments on their cell surface along with major histocompatibility complex $(\mathrm{MHC})$ antigens after capturing cancer antigens. The complex of cancer antigens and MHC class I antigens are presented to $\mathrm{CD} 8^{+}$cytotoxic T lymphocytes (CTLs), while the complex of cancer antigens and MHC class II antigens engage to stimulate $\mathrm{CD}^{+}$helper T-cells. The CD4 ${ }^{+}$helper $\mathrm{T}$ cells enhance the differentiation of CTLs into effecter T-cells by secreting cytokines such as interferon- $\mathrm{Y}$ (IFN- $\mathrm{\gamma}$ ) and interleukin-2 (IL-2).

Naïve T-cells receive the presentation of cancer antigens from DCs in the T-cell zones of lymphoid organs to acquire an appropriate immune response ${ }^{[24]}$. To achieve antigen presentation, these two cells constantly migrate to the lymphoid organs (homing). 


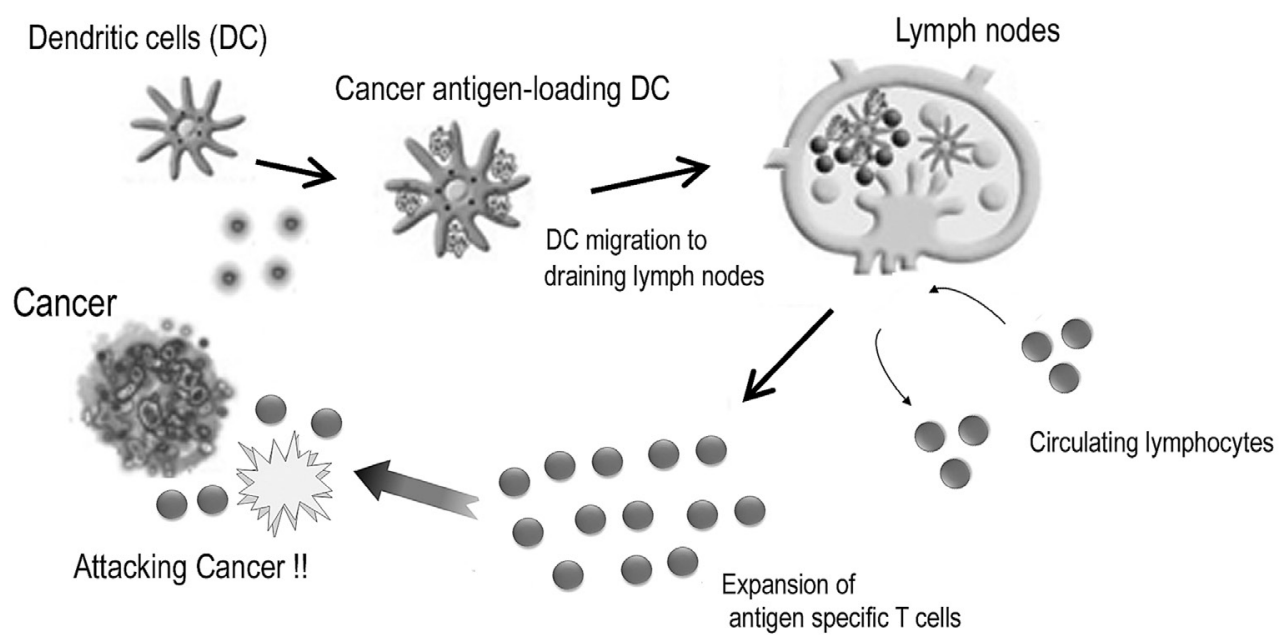

Figure 1: T-cell-mediated immune responses against cancer ${ }^{[76]}$

The homing mechanism is regulated by chemokines and the chemokine receptor axis. CCL21 and CCL19 are homeostatic chemokines that are constantly secreted from secondary lymphoid organs, including lymph nodes and Peyer's patches, without any exogenous stimulation ${ }^{[25-27]}$. Meanwhile, C-C chemokine receptor 7 (CCR7) is a concomitant chemokine receptor of CCL21 and CCL19 ${ }^{[25]}$. Cells expressing CCR7 can migrate to organs where CCL21 and CCL19 are secreted depending on the concentration gradient ${ }^{[28]}$. Most naïve T-cells constantly express CCR7. DCs matured by exogenous stimulation with antigens derived from bacteria or cancers begin to express CCR7, whereas immature DCs do not express CCR7 ${ }^{[24,29]}$. Thus naïve T-cells and antigen-presenting DCs can migrate to secondary lymphoid organs from peripheral organs. As a final step in homing, these immune cells need to carry out transvasation through high endothelial veins to infiltrate into the lymphatic organs from the lymphatic system. To complete homing through the interval between endothelial cells, expression of adhesion molecules such as L-selectin and integrin is up-regulated for rolling and adhesion with intercellular adhesion molecule (ICAM), which is a co-receptor for integrin ${ }^{[30,31]}$. After antigen presentation, T-cells are induced to proliferate and differentiate into effecter T-cells. The expression of CCR7 on T-cells is then down-regulated to leave the lymphoid tissue for migration to cancer tissues.

Effecter T-cells recognize the complex of cancer antigens and MHC class I antigens expressed on cancer cells through a T-cell receptor (TCR). Then, the lethal effects against cancer cells are triggered along two different pathways: granule exocytosis and death ligand/death receptor system. Granule exocytosis induces the secretion of perforins and granule enzymes (granzymes ${ }^{[32,33]}$. Even though the nature and the role of these proteases in response to cancer is still unclear, perforins generally act as a carrier for the delivery of granzymes and build pores in the plasma membrane of target cells to allow granzymes to gain entry to the target cell cytosol. Granzymes are considered to execute the target cells through the cleavage of factors required for replication and defense ${ }^{[33]}$. Death ligands are proteins including Fas ligand (FasL) that is expressed on effector T-cells. FasL can engage target cells through the Fas receptor, which belongs to the tumor necrosis factor (TNF) superfamily, to induce target cell death by apoptosis ${ }^{[34]}$. The main role of FasL is to regulate the immune system, but cancer cells may over-express FasL spontaneously or as chemotherapy resistance to make a countercharge by inducing the apoptosis of tumor-infiltrating lymphocytes (TILs) to escape from the immune system ${ }^{[34]}$.

\section{T-cell based immunotherapy for cancer}

As has been mentioned, the human immune system always works in response to antigens expressed on cancer cells, thus distinguishing cancer cells from noncancerous cells. This causes the induction of TILs to be found in the tumor microenvironment ${ }^{[35]}$. However, anticancer immunity is usually not enough to overcome the tumor's growing speed owing to the low immunogenicity of cancer cells because these cells are derived from an individual's own cells. Thus, it was inevitable that immunotherapy would be developed to overcome the low immunity against cancer. With regard to T-cell-based immunotherapy, adoptive transfer of CD3-activated T-cells has been induced traditionally as a compulsory activation stimulus to compensate for the reduction in stimulation frequency due to low antigenicity. Moreover cancer-specific-antigen loaded DC vaccines are also utilized to induce more types of cancer-specific T lymphocytes. 
The more recent discovery of immune check-point inhibitors achieved outstanding progress in cancer immunotherapy by showing sensational longterm benefits in patients with advanced cancer ${ }^{[4,5]}$. The purpose of this medicine is to inhibit immune suppressive signals between cancer cells and T-cells; thus the agent that eliminates a cancer during the final phase is T-cells ${ }^{[36,37]}$. Immune check-point molecules such as programmed death-1 (PD-1) and T-lymphocyteassociated antigen 4 (CTLA4) are expressed on T cells and play a vital role in limiting the exaggerated immune response in both adaptive immune response and autoimmune response to maintain homeostasis by acting as an inhibitory signal against APCs. Recently, it has been disclosed that cancer cells take advantage of this mechanism to survive. For example, cancer cells express PD-L1, which is a concomitant ligand against PD-1, to attenuate T-cell-based immune reactions in association with cancer progression. With the discovery of this mechanism, immune check-point inhibitors have been shown to carry great promise. However, its efficacy has only been recognized still in a small number of patients, and PD-L1 expression on tumor cells has been regarded as a negative prognostic factor ${ }^{[4,5]}$.

\section{Hyperthermia enhances immune systems in response to cancer}

Body temperature elevation has been considered an important phenomenon associated with regulation in both innate and adaptive immune responses ${ }^{[38]}$. Hyperthermia elicits various effects in several steps of the immune reaction for cancer. It up-regulates the homing of immune cells and the function of adhesion molecules on both immune cells and endothelial cells, activating immune cells including CTLs, DCs, and NK cells, and inhibiting immune suppression. In this section, we discuss how thermal stress up-regulates the immune system.

Hyperthermia, especially whole body hyperthermia, has the potential to increase the homing of immune cells. Continuous secretion of homeostatic chemokines including CCL21 and the expression of adhesion factors including selectin, integrin, and ICAM regulate immune homeostasis by maintaining the homing of these immune cells. Thermal effect can enhance the expression of ICAM-1 and CCL21 in high endothelial venules $(\mathrm{HEVs})^{[39]}$ and can up-regulate L-selectin- and integrin-dependent adhesive interaction to induce the adhesion and migration of DCs and T-cells toward $\mathrm{HEVs}^{[40]}$. Additionally, increases in the migration capacity of DCs ex vivo has been reported ${ }^{[41]}$.

We reported previously that heat treatment stimulated cytokine production from peripheral T-cells in vitro and in vivo in fresh peripheral venous blood obtained from 5 healthy volunteers ${ }^{[42]}$. We first incubated peripheral blood mononuclear cells (PBMCs) separated from obtained blood samples at $37{ }^{\circ} \mathrm{C}$ or $39^{\circ} \mathrm{C}$ for $2 \mathrm{~h}$ in a water bath, then PBMCs were co-cultured with antiCD3/CD28 monoclonal antibodies for $24 \mathrm{~h}$ at $37^{\circ} \mathrm{C}$. To evaluate the secretory properties of cytokines in T-cells, IFN-y and IL-2 levels in the supernatant were measured. Results showed that both cytokine production levels were significantly increased (approximately twofold) when PBMCs were cultured at $39{ }^{\circ} \mathrm{C}$ [Figure 2]. Next, the volunteers underwent whole body hyperthermia until the rectal temperature reached $38.5^{\circ} \mathrm{C}$ (generally it required $1 \mathrm{~h}$ of treatment). After terminating heating, volunteers were covered with a leather tent for $60 \mathrm{~min}$ as a heat-retention phase. Blood samples were obtained four times: before the treatment, at the end of the heat-retention phase, and then 24 and $48 \mathrm{~h}$ after
IFN- $\gamma$

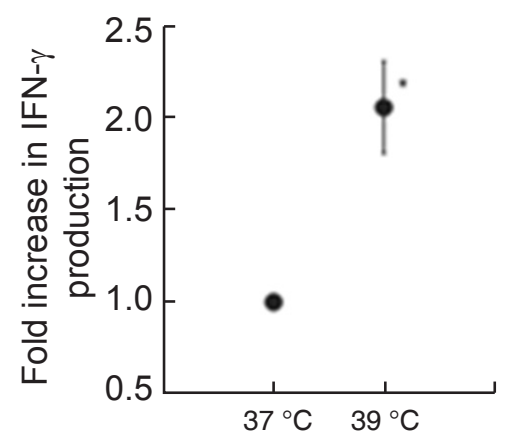

IL-2

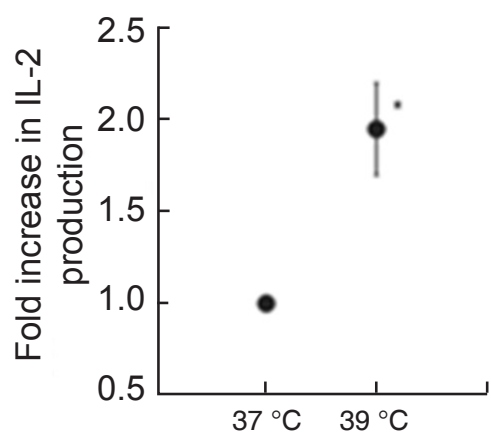

Figure 2: In vitro hyperthermia stimulates IFN- $\gamma$ and IL-2 production from T-cells stimulated with monoclonal antibodies against $\mathrm{CD} 3$ and CD28. Blood samples were collected and incubated at $37^{\circ} \mathrm{C}$ and $39{ }^{\circ} \mathrm{C}$ for $2 \mathrm{~h}$, then PBMCs were extracted and co-cultured with monoclonal antibodies against CD3 and CD28 to measure IFN- $\gamma$ and IL-2 production levels in each supernatant. Results are shown as twofold over the control $\left(37^{\circ} \mathrm{C}\right)$ for the average of five separate donors, and expressed as mean \pm SEM. Statistical differences from the control were evaluated using paired $t$-test. $P<0.05$ was recognized as statistically significant ${ }^{[42]}$. IFN: interferon; IL: interleukin; PBMCs: peripheral blood mononuclear cells 
treatment. IFN- $\gamma$ and IL-2 levels in each supernatant were measured in response to monoclonal antibody against CD3 and CD28. The results showed significant increases in the production of both IFN-y and IL-2; these were observed not only immediately after but also $24 \mathrm{~h}$ after whole body hyperthermia. At $48 \mathrm{~h}$ after whole body hyperthermia, the production levels of both cytokines had returned to the pretreatment levels [Figure 3].

The potential mechanisms that stimulate cytokine production after hyperthermia may be explained by an increase in the membrane fluidity of T-cells. It was reported that physiological heat stress enhanced the membrane fluidity of T-cells. It also showed an increase in the cluster formation of the $\mathrm{GM} 1^{+} \mathrm{CD}$-microdomain in $\mathrm{CD}^{+} \mathrm{T}$-cells, clustering TCR $\beta$ and the CD8 coreceptor, and enhanced conjugate formation between T-cells and APCs in mice ${ }^{[43]}$. These results suggest that a heat-stress-induced increase in membrane fluidity is one of the primary events, and it subsequently triggers a cascade of molecular events that eventually make $T$ cells crosstalk more rapidly and efficiently with APCs. These cellular events, including the formation of TCR microclusters, consist of several adhesion and signaling molecules ${ }^{[44]}$, which accumulate at the immune synapse ${ }^{[45]}$. This is also known as the central supramolecular activation complex ${ }^{[46]}$.

Heat-shock proteins (HSPs) have been considered to play an important role in the effects of heat treatment on T-cell function. Indeed, the synthesis of HSPs was shown to increase with elevated body temperature in fever-range whole-body hyperthermia ${ }^{[4]}$. The essential function of HSPs is known to involve their actions as molecular chaperones. As part of this function, HSPs are involved in antigen presentation and cross- presentation in DCs by delivering chaperoned antigenic peptides to MHC class I molecules, thereby inducing antigen-specific T-cell activation ${ }^{[48-50]}$. It was reported that the presence of recombinant Hsp60 allows antigendependent T-cell activation with antigen-specific IFN-y secretion in conditions when even stimulation is not sufficient to activate T-cells ${ }^{[51]}$.

In contrast, Hsp70 is also expressed in cancers and acts as an effective inhibitor of apoptosis caused by heat stress, thereby participating in tumor progression ${ }^{[52]}$. Hsp70 can prevent aggregation, remodel folding pathways, and regulate activity of cancer cells ${ }^{[53]}$. However, the effects of HSPs on DCs and T-cells are still contradictory ${ }^{[54]}$. Thus, the function of HSPs must continue to be investigated in order to clarify whether and how HSPs are involved in antigen presentation between T-cells and DCs during heat stress.

NK cells can behave as a spearhead of the innate immune response toward exogenous antigens and can make an initial attack against targets without prior exposure to the specific antigens. Basically, normal cells express MHC class I molecules, whereas aberrant cells such as cancer cells extinguish the expression of MHC class I molecules on themselves ${ }^{[5]}$. This phenomenon was especially observed in pancreatic ${ }^{[56]}$, cervical $^{[57]}$, breast ${ }^{[58]}$, prostatic ${ }^{[59]}$, and penile cancer ${ }^{[60]}$. Down-regulation of MHC class I molecules on cancer cells is one of the steps for immune escape from cancer-specific immune response by T-cells, because abnormal antigens must be presented with $\mathrm{MHC}$ class I molecules when T-cells recognize them. In contrast to T-cells, NK cells target cells that have lost the expression of MHC class I molecules, because NK cells express inhibitory receptors that engage with $\mathrm{MHC}$ class I antigens. Hence, the anticancer ability of

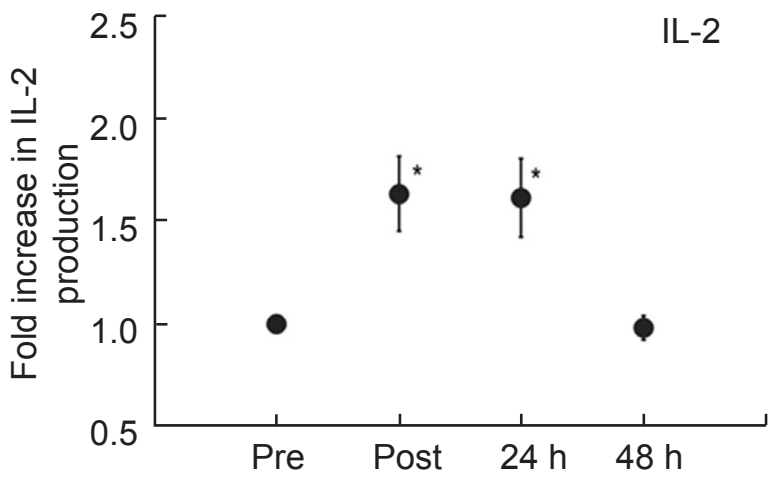

Figure 3: Whole-body hyperthermia stimulates IFN- $\gamma$ and IL-2 production from T-cells. Blood was obtained from donors before (Pre), immediately after (Post), $24 \mathrm{~h}$ after $(24 \mathrm{~h})$, and $48 \mathrm{~h}$ after $(48 \mathrm{~h})$ whole-body hyperthermia. PBMCs from each time point were extracted and co-cultured with monoclonal antibodies against CD3 and CD28 to measure IFN- $\gamma$ and IL-2 production levels in each supernatant. Results are shown as fold over the control (Pre) for the average of five separate donors, and expressed as mean \pm SEM. Statistical differences from control was evaluated using paired $t$-test. $P<0.05$ was recognized statistically significant ${ }^{[42]}$. IFN: interferon; IL: interleukin; PBMCs: peripheral blood mononuclear cells 
A

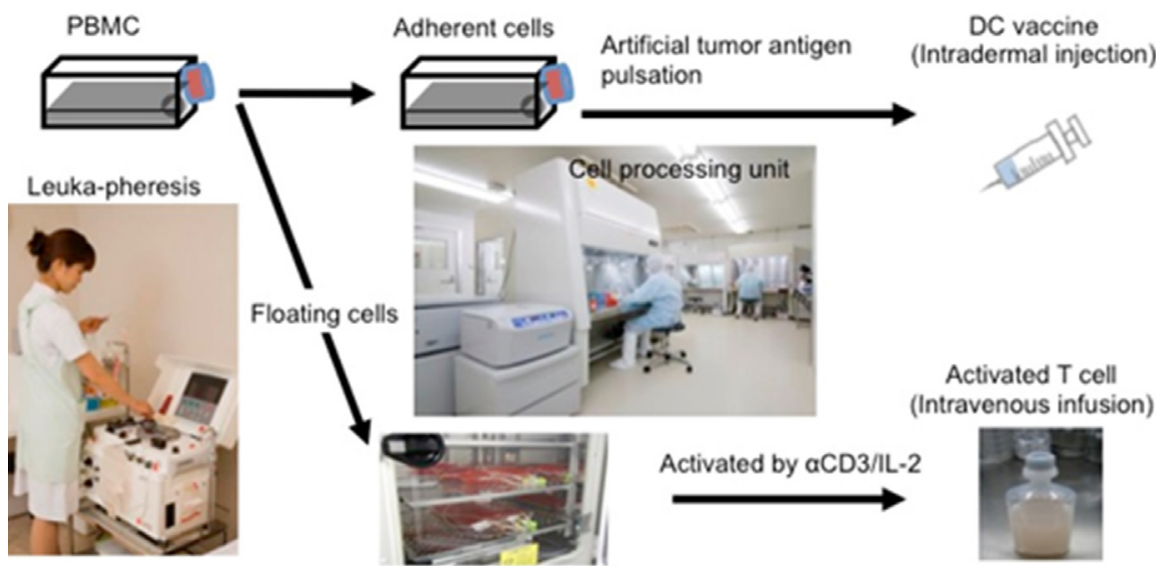

B

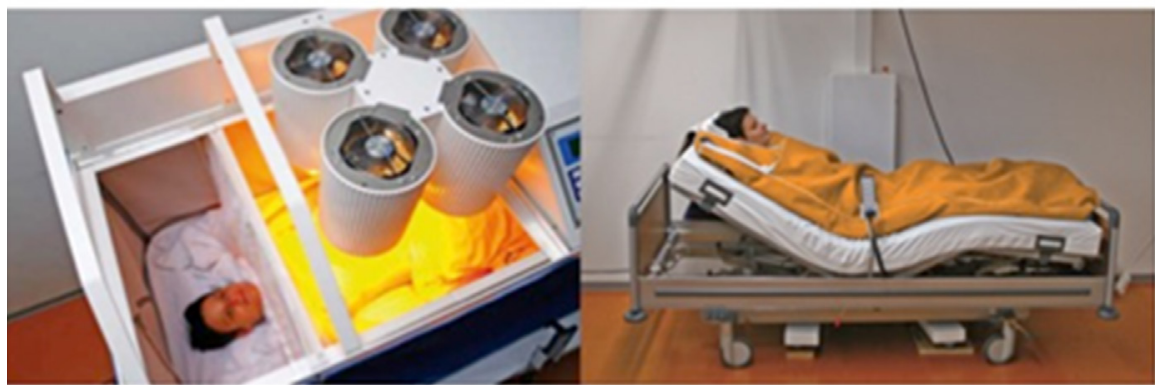

Heating phase

Retention phase

C

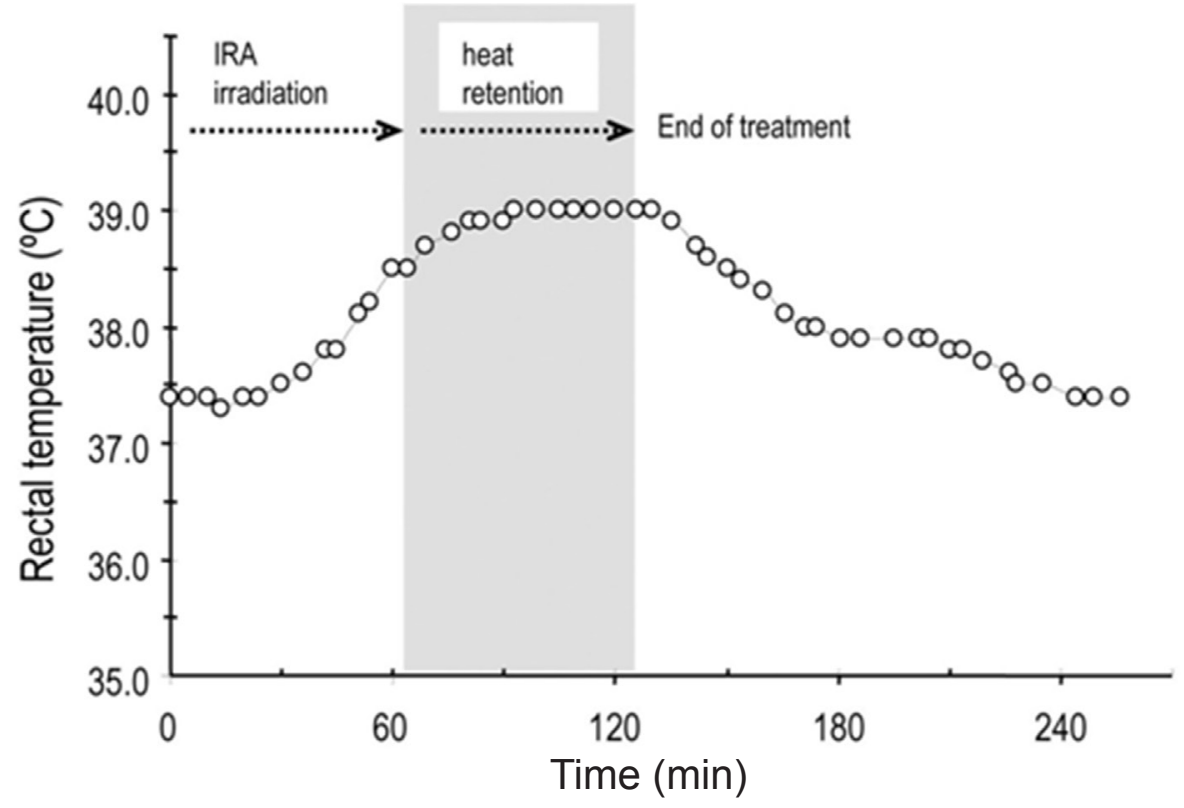

Figure 4: Approach for immunotherapy with whole-body hyperthermia. (A): cell preparation for DC vaccine and activated-T-cell therapy; (B): fever-range hyperthermia using heckle HT-3000 device; (C): representative data of body temperature during whole-body hyperthermia. DC: dendritic cell; PBMCs: peripheral blood mononuclear cells

NK cells is exercised at this time to complement T-cellbased immune reactions owing to attenuated inhibitory signals between NK cells and cancer cells ${ }^{[61]}$. Activated NK cells have nonspecific anticancer potential by secreting cytotoxic molecules including perforin and granzyme ${ }^{[33]}$ and death receptors such as FasL, TRAIL, and TNF- $\alpha^{[62,63]}$. Additionally, heat stress can enhance the distinct clustering of NK cell-activating receptors such as NKG2D on the surface of NK cells and the expression of NK cell-activating ligands, including major histocompatibility complex class I-related chain A $(\mathrm{MICA})^{[64,65]}$. Moreover, an increase in the expression of 

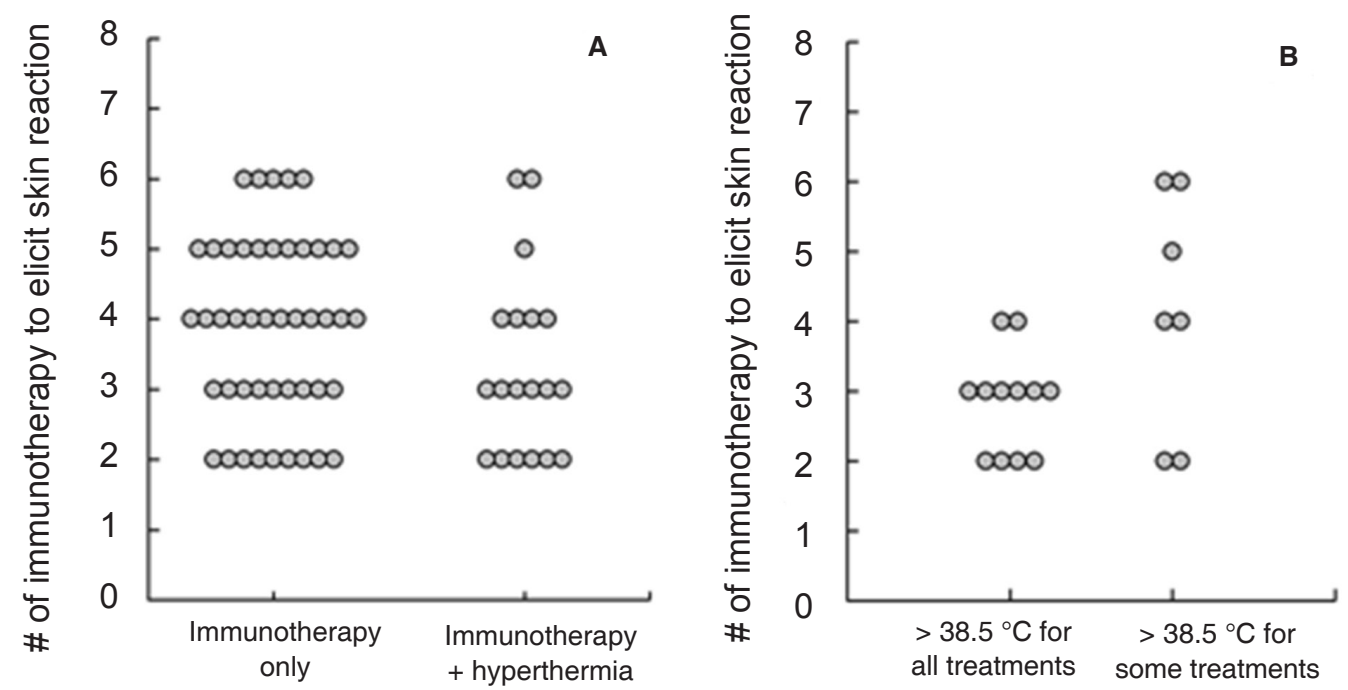

Figure 5: Required number of immunotherapy injections with DC vaccine and activated T-cells to elicit DTH-like skin reaction. (A): comparison between patients who received immunotherapy alone or in combination use with hyperthermia; (B): comparison of patient's rectal temperatures during hyperthermia ${ }^{[76]}$. DC: dendritic cell; DTH: delayed type hypersensitivity

MICA and increased cytotoxicity of NK cells were also observed in several cancer cell lines ${ }^{[66]}$. Concerning the contribution of NK cells to cancer-specific immune responses, after an initial attack, fragments including cancer antigens of tumor cells are generated as a result of the interaction of the tumor and NK cells. These cancer antigens are recognized by DCs for T-cellbased cancer-specific immune responses. Additionally, activated NK cells secrete cytokines including IFN-y and IL-2 to enhance acquired immune responses with immunoglobulin production from B-cells and activation of T-cells ${ }^{[5,61]}$. This perception leads to the conclusion that increasing the function of NK cells by hyperthermia could be expected to result in the augmentation not only of nonspecific anticancer immune reactions regulated by NK cells but also of specific anticancer immune reactions regulated by T-cells and DCs.

To avoid exaggerated immune responses that cause harmful effects on the body, the immune system is regulated to limit adaptive immune responses and prevent autoimmune responses and auto-inflammatory reactivity in the normal situations. To achieve this, our immune system combines immunological tolerance system. Regulatory T cells (Tregs) are a subpopulation of T-cells, expressing CD4, CD25, and FOXP3, which negatively modulate both innate and adopted immune response by down-regulating or suppressing induction and proliferation of immune cells including T cells, DCs, and NK cells ${ }^{[67-69]}$. Even though Tregs usually account for about $4 \%$ of $C D 4^{+} T$ cells, they can make up as much as $20-30 \%$ of the total $\mathrm{CD} 4^{+}$population in the tumor microenvironment and are associated with poor prognosis in many cancers, such as ovarian, breast, renal, and pancreatic cancer ${ }^{[70]}$. Depletion of Tregs in animal models has been shown to increase the efficacy of immunotherapy. So, achieving the depletion of Tregs is one of the pivotal targets of recent research and therapy associated with cancer immunology ${ }^{[71]}$. The potential effect of hyperthermia is considered to enhance the cytotoxicity of NK cells against Tregs, and to inhibit the induction of Tregs while the apoptosis of Tregs is induced. A significant decrease in the number of Tregs was observed while NK cell activity and the percentage of NK cells increased in peripheral blood samples of healthy volunteers after irradiation of feverrange hyperthermia to the upper abdominal region ${ }^{[72]}$. Moreover, combination therapy of intratumoral injection of immature DCs and local hyperthermia for patients with advanced malignant melanoma demonstrated decreased infiltration of Tregs and increased infiltration of activated CTLs, even though there was no statistical difference in overall survival time ${ }^{[73]}$.

The efficacy of hyperthermia in down-regulating the expression of PD-L1 in some cancer cell lines was reported. In this study, decreased expression of PDL1 in cancer cell lines was shown when samples were exposed to temperatures between $40^{\circ} \mathrm{C}$ and $43^{\circ} \mathrm{C}^{[74]}$. Further accumulation of data associated with this new experimental model is eagerly awaited.

\section{Combination therapy with immunotherapy}

Hyperthermia has been reported to enhance the efficacy of $\mathrm{DC}$ vaccines by up-regulating IFN- $\gamma$ secretion to stimulate naïve T-cells, enhancing DC migration toward lymphatic organs and protecting DC from apoptosis ${ }^{[75]}$. We introduced a whole body hyperthermia device 
(HECKEL HT3000, Heckel medizintechnik GmgH, Esslingen, Germany), and have performed combination therapy with adoptive transfer of CD3-activated T-cells and cancer-antigen loaded DC vaccines. Patients with various solid tumors were vaccinated once a week with $\mathrm{DC}$ vaccine prepared from autologous monocytederived DCs, which were pretreated with tumor antigens. The DC vaccine was injected intradermally near the inguinal lymph nodes and CD3-activated T-cells were administered intravenously [Figure 4A]. Some patients underwent whole-body hyperthermia at the same time, with the target rectal temperature set at $38.5{ }^{\circ} \mathrm{C}$ and heat-retention for another $1 \mathrm{~h}$ [Figure $4 \mathrm{~B}$ and $\mathrm{C}$ ]. To evaluate the induction of immune responses in patients who received antigen-loaded DC vaccination, we examined the onset of skin reaction at the vaccination site because this reaction indicates antigen-specific T-cell responses against tumor antigens presented by DC vaccine. Then, we examined how much DC vaccination was required in each patient up to the point when delayed hypersensitivity like skin reaction sizes $48 \mathrm{~h}$ after DC vaccination became consistently larger than $1.5 \mathrm{~cm}$ in diameter. The average number of vaccinations to induce skin reaction was 3.87 and 3.32 in patients without and with whole-body hyperthermia, respectively [Figure 5A]. Moreover, 12 of 19 patients who underwent whole-body hyperthermia successfully elevated their core body temperature above $38.5^{\circ} \mathrm{C}$ in every treatment and displayed earlier expression of skin reaction [Figure 5B]. This result indicated that the combined use of hyperthermia with a $\mathrm{DC}$ vaccine and activated T-cells had a positive impact on the induction of T-cell based immune responses ${ }^{[76]}$.

\section{Combination therapy with radiotherapy}

The enhancement of anticancer efficacy of combination use of radiotherapy and hyperthermia was clinically recognized in cervical, breast, and head and neck cancer and so on ${ }^{[77]}$. Even though radiological cytotoxicity induces DNA damage of cancer cells ${ }^{[78]}$, some cancer cells can come back into existence (termed sublethal damage repair or lethal damage repair) ${ }^{[7,80]}$. In the analysis of the cell cycling, quiescent tumor cells were more resistant to irradiation because cells in this stage have the potential for lethal damage repair ${ }^{[81]}$. In contrast, hyperthermia can inhibit the repair of radiation-induced damage in cancer cells, so that combination use of hyperthermia can enhance the anticancer efficacy of radiotherapy ${ }^{[2,83]}$. Cells in the synthesis (S) phase are also relatively radio-resistant, while they are the most sensitive to hyperthermia. Additionally, hypoxic cells in tumors are also radioresistant, while hyperthermia improves the anaerobic condition by oxygen delivery due to increased blood flow. These perceptions indicate the synergetic effect of combination use of radiotherapy and hyperthermia ${ }^{[7]}$. Moreover, additional use of DNA repair inhibitors was reported to further enhance its efficacy ${ }^{[84]}$.

\section{Combination therapy with chemotherapy}

Chemotherapy is the most popular therapeutic method for patients with inoperative cancer and recurrent or metastatic cancer; however, there are serious problems including its uncertain efficacy, drug resistance, and adverse effects. To improve therapeutic results, combination use of hyperthermia was tested, and increased anticancer effect was reported in paclitaxel, docetaxel, gemcitabine, oxaliplatin, and irinotecan ${ }^{[85]}$. The mechanism of interaction of chemotherapy and hyperthermia was considered as follows: increased drug uptake into cancer cells by causing damage to the membrane of cancer cells and reducing oxygen radical detoxification. Eventually, DNA damage increased while DNA repair decreased. Additionally, hyperthermia was reported to have a potential ability to avoid drug resistance ${ }^{[86,87]}$. In addition, it is also expected that elevated blood flow could result in a relative increase in anticancer drug concentration within the tumor. Moreover, adverse effects can be decreased because increased drainage of the drugs may accelerate in normal cells due to the up-regulation of metabolism. On the other hand, some anticancer drugs, including 5-fluorouracil, gemcitabine, and oxaliplatin, are considered to enhance cancer immunity by inducing the infiltration of CTLs while reducing Tregs in the tumor ${ }^{[88]}$. Accordingly, enhancing the efficacy of chemotherapy will result secondarily in up-regulation of cancer immunity.

\section{Combination therapy with surgery}

Chemotherapy is usually performed for peritoneal metastases, but its prognosis is nonetheless bad, because blood flow to the peritoneum is poor owing to the presence of the peritoneal-plasma barrier ${ }^{[89]}$. Hyperthermic effects are considered to impair the peritoneal-plasma barrier and result in increased resorption of anticancer drugs in peritoneal tumors. Hence, the combination of hyperthermia and chemotherapy by intraperitoneal administration resulted in more anticancer drug accumulation in peritoneal tumors than after chemotherapy alone ${ }^{[90]}$. Using this concept, the effectiveness of cytoreductive surgery with subsequent HIPEC has been reported for peritoneal metastasis from gastric ${ }^{[91]}$, colorecta|[92,93], appendiceal ${ }^{[94]}$, and adrenal cancer ${ }^{[95]}$. Generally HIPEC is performed after resection of the cancer lesion with or without systemic peritonectomy by intraperitoneal administration of an anticancer drug containing saline, which is heated in advance to maintain the peritoneal 
surface at around $43^{\circ} \mathrm{C}$ while irrigating the drug solution.

Adjuvant chemotherapy is often given after surgery for certain types of cancer, such as pancreatic, colorectal, and breast cancer, to improve prognosis by reducing the potential for recurrence and metastasis ${ }^{[96-99]}$. However, in some cancers, including intrahepatic cholangiocarcinoma (ICC), the prognosis of patients is extremely poor because the recurrence rate after curative operation is very high and there is no standard adjuvant setting. We reported previously that postoperative adjuvant immunotherapy with intradermal administration of a DC vaccine and intravenous administration of activated T-cells would be a feasible and effective treatment for preventing recurrence and achieving long-term survival in patients with ICC. In this study, the median 5-year progression-free survival and overall survival were 18.3 and 31.9 months in the patients receiving adjuvant immunotherapy, and 7.7 and 17.4 months in the group with surgery alone $(P=0.005$ and 0.022 , respectively). Additionally, patients whose skin reactions at the vaccine site were $\geq 3 \mathrm{~cm}$ showed dramatically better prognosis in patients receiving adjuvant immunotherapy ${ }^{[100]}$. As has been explained above, hyperthermia can elicit early skin reactions when used in conjunction with immunotherapy including with DC vaccines and activated T-cell transfer ${ }^{[76]}$. Hyperthermia can also augment the efficacy of adoptive immunotherapy by up-regulating IFN-y secretion to stimulate naïve T-cells, and enhancing homing of DCs and T-cells ${ }^{[75]}$. For the reasons stated above, hyperthermia is considered to be useful for adjuvant settings.

Neoadjuvant chemotherapy and chemoradiotherapy have become well established, especially for esophageal cancer patients ${ }^{[101]}$. These neoadjuvant therapies improved the long-term survival rate, but the therapeutic benefit was sometimes countered by a significant increase in adverse effects ${ }^{[102]}$. In addition, postoperative complications, including cardiac diseases and pulmonary diseases, are much more severe after chemoradiotherapy ${ }^{[103,104]}$. Preoperative radiotherapy increases the risk of postoperative anastomosis leakage, an unfavorable complication. As has been mentioned above, hyperthermia has the potential to augment the effects of chemotherapy or radiotherapy. Combination use of hyperthermia with chemotherapy or radiotherapy may be useful even in the neoadjuvant setting to suppress the possibility and seriousness of adverse effects and complications by reducing the dose of chemotherapy or radiotherapy required while maintaining or increasing its anticancer effects. Indeed, in 1995, the result of a randomized phase III study for patients with resectable squamous cell carcinoma of the thoracic esophagus was disclosed. Patients underwent neoadjuvant chemoradiotherapy with or without radiofrequency wave local hyperthermia, and the 3-year survival rate was $24.2 \%$ and $50.4 \%$, respectively. There were no procedural complications ${ }^{[105]}$. Additionally, in 2010, the results of a randomized phase III trial of patients with high-risk soft-tissue sarcoma were reported. Patients underwent neoadjuvant chemotherapy consisting of etoposide, ifosfamide, and doxorubicin with or without local hyperthermia. The treatment response rate in the group that received regional hyperthermia was $28.8 \%$, compared with $12.7 \%$ in the group with chemotherapy alone $(P=0.002)^{[106]}$.

During the postoperative period, immunity is suppressed by operative invasion ${ }^{[107]}$ and the administration of anesthetic drugs such as opioids ${ }^{[108]}$, and it results in the encouragement of postoperative cancer metastasis ${ }^{[109]}$. Concerning the biological effect, preoperative feverrange whole-body hyperthermia was reported to augment postoperative cancer immunity by increasing the blood level of TNFa and HSP60[77]. Thus, hyperthermia increased the benefit of neoadjuvant therapy.

\section{Adverse effects of hyperthermia}

Adverse effects of acute or chronic periods of regional hyperthermia do not develop often and are usually minor, owing to a recent development of heating techniques and thermometry, or treatment schedule ${ }^{[110]}$. Adverse effects of hyperthermia include skin burns and skin pain, but these events usually heal spontaneously[111]. In terms of combination therapies with hyperthermia, radiation toxicity is not increased, but toxicity of chemotherapy might be enhanced depends on the increase in drug efficacy ${ }^{[110]}$. In rare settings of combination therapy with chemotherapy, the formation of severe subcutaneous fat or muscle necrosis that required surgery to cure was reported. Adverse effects of regional hyperthermia vary with the type of targeted organ or heating device and techniques. Whole body hyperthermia is a slightly more invasive hyperthermal method accompanied by a feeling of heat, tiredness, and loss of sweat due to a rapid elevation of the core body temperature. Dehydration, heat illness, cardiac disease, or thrombosis might appear depending on underlying disease or physical condition. In addition, whole body hyperthermia has a risk for toxicity to the peripheral nervous system. Hence, this method is contraindicated for patients with neurodegenerative diseases, such as multiple sclerosis ${ }^{[12]}$.

On the other hand, no reports that describe hyperthermia having a positive impact on cancer progression in 
regard to biological effects are found until now.

Overall, hyperthermia is considered a convenient therapeutic method so long as it is used appropriately. Paradoxically, the safety of hyperthermia is maintained by avoiding excess irradiation with the purpose of deep heating, because it is still difficult to aggregate the heat effect only in cancer tissue. By using hyperthermia in combination with chemotherapy or radiotherapy, the dose of these therapies may be reduced to ease their side-effects without reducing therapeutic effects, because hyperthermia has the potential to augment the effect of chemotherapy or radiotherapy in a less invasive manner.

\section{CONCLUSION}

This report shows that hyperthermia increases the advantage of the following biological features. Heat stress lowers the survival rate of all cells, but normal tissues are better able to tolerate this than cancerous tissues. Heat has a potential to augment immune responses while decreasing immune suppression. Heat inhibits the recovery of cancer cells from DNA damage. Heat enhances the resorption of anticancer drugs into cancer cells. The sensitivity of cancer cells against heat and radiation differs depending on the condition of cancer cells in the cell cycle. The anticancer efficacy of hyperthermia alone with currently available heating devices is not enough to suggest its use as a standalone therapy. However, some studies have shown that combination therapy with conventional methods including immunotherapy, radiotherapy, chemotherapy, and surgery improves its anticancer efficacy in vitro and vivo.

\section{Perspective}

Currently, clinical experience and data of oncological hyperthermia are still limited because both information and devices for hyperthermia have not become common. Therefore, multicenter clinical trials for cancer treatment including hyperthermia should be done to provide convincing data. The combination hyperthermia with immune check-point inhibitors should be involved in these studies to achieve fuller anticancer efficacy with fewer adverse effects. Development of drugs such as DNA repair inhibitors or regulators of HSPs is also expected to augment the efficacy of hyperthermia itself. Additionally, further efforts will be required to solve the mechanism of the involvement of cancer and hyperthermia to optimize cancer therapy. The development of heating devices and thermometry is also needed to achieve more appropriate heat delivery that is limited to the tumor lesion.

\section{DECLARATIONS}

\section{Authors' contributions}

Designed and wrote the manuscripts: Y. Yagawa

Conducted IFN-Y and IL-2 production assays: Y. Kobayashi

Provided suggestions on the revision of the manuscripts: M. Yamamoto

Built Figures 1, 4 and 5 and revised the manuscript: K. Tanigawa

\section{Financial support and sponsorship None.}

\section{Conflicts of interest}

There are no conflicts of interest.

\section{Patient consent}

Not applicable.

\section{Ethics approval}

Not applicable.

\section{REFERENCES}

1 Navin N, Kendall J, Troge J, Andrews P, Rodgers L, McIndoo J, Cook K, Stepansky A, Levy D, Esposito D, Muthuswamy L, Krasnitz A, McCombie WR, Hicks J, Wigler M. Tumour evolution inferred by single-cell sequencing. Nature 2011;472:90-4.

2. Griffith KD, Read EJ, Carrasquillo JA, Carter CS, Yang JC, Fisher B, Aebersold P, Packard BS, Yu MY, Rosenberg SA. In vivo distribution of adoptively transferred indium-111-labeled tumor infiltrating lymphocytes and peripheral blood lymphocytes in patients with metastatic melanoma. J Natl Cancer Inst 1989;81:1709-17.

3. Rosenberg SA, Aebersold P, Cornetta K, Kasid A, Morgan RA, Moen R, Karson EM, Lotze MT, Yang JC, Topalian SL, Merino MJ, Culver K, Dusty Miller A, Michael Blaese R, French Anderson W. Gene transfer into humans--immunotherapy of patients with advanced melanoma, using tumor-infiltrating lymphocytes modified by retroviral gene transduction. $N$ Engl J Med 1990;323:570-8.

4. Wolchok JD, Weber JS, Maio M, Neyns B, Harmankaya K, Chin K, Cykowski L, de Pril V, Humphrey R, Lebbé C. Four-year survival rates for patients with metastatic melanoma who received ipilimumab in phase II clinical trials. Ann Oncol 2013;24:2174-80.

5. Balar AV, Weber JS. PD-1 and PD-L1 antibodies in cancer: current status and future directions. Cancer Immunol Immunother 2017;66:551-64.

6. Mackowiak PA. Concepts of fever. Arch Intern Med 1998;158:187081.

7. Dewey WC, Hopwood LE, Sapareto SA, Gerweck LE. Cellular responses to combinations of hyperthermia and radiation. Radiology 1977;123:463-74.

8. Dewhirst MW, Viglianti BL, Lora-Michiels M, Hanson M, Hoopes PJ. Basic principles of thermal dosimetry and thermal thresholds for tissue damage from hyperthermia. Int J Hyperthermia 2003;19:26794.

9. Hall EJ, Roizin-Towle L. Biological effects of heat. Cancer Res 1984;44:s4708-13.

10. Luk KH, Purser PR, Castro JR, Meyler TS, Phillips TL. Clinical 
experiences with local microwave hyperthermia. Int J Radiat Oncol Biol Phys 1981;7:615-9.

11. Manning MR, Cetas TC, Miller RC, Oleson JR, Connor WG, Gerner EW. Clinical hyperthermia: results of a phase I trial employing hyperthermia alone or in combination with external beam or interstitial radiotherapy. Cancer 1982;49:205-16.

12. Gabriele P, Orecchia R, Ragona R, Tseroni V, Sannazzari GL. Hyperthermia alone in the treatment of recurrences of malignant tumors. Experience with 60 lesions. Cancer 1990;66:2191-5.

13. Masunaga S, Nagasawa H, Uto Y, Hori H, Suzuki M, Nagata K, Kinashi Y, Ono K. The usefulness of continuous administration of hypoxic cytotoxin combined with mild temperature hyperthermia, with reference to effects on quiescent tumour cell populations. Int $J$ Hyperthermia 2005;21:305-18.

14. Song CW. Effect of local hyperthermia on blood flow and microenvironment: a review. Cancer Res 1984;44:s4721-30.

15. Lepock JR, Frey HE, Heynen MP, Nishio J, Waters B, Ritchie KP, Kruuv J. Increased thermostability of thermotolerant CHL V79 cells as determined by differential scanning calorimetry. J Cell Physiol 1990;142:628-34.

16. Abe M, Hiraoka M, Takahashi M, Egawa S, Matsuda C, Onoyama Y, Morita K, Kakehi M, Sugahara T. Multi-institutional studies on hyperthermia using an $8-\mathrm{MHz}$ radiofrequency capacitive heating device (Thermotron RF-8) in combination with radiation for cancer therapy. Cancer 1986;58:1589-95.

17. Song CW, Rhee JG, Lee CK, Levitt SH. Capacitive heating of phantom and human tumors with an $8 \mathrm{MHz}$ radiofrequency applicator (Thermotron RF-8). Int J Radiat Oncol Biol Phys 1986;12:365-72.

18. Hegyi G, Szasz O, Szasz A. Oncothermia: a new paradigm and promising method in cancer therapies. Acupunct Electrother Res 2013;38:161-97.

19. Sulyok I, Fleischmann E, Stift A, Roth G, Lebherz-Eichinger D, Kasper D, Spittler A, Kimberger O. Effect of preoperative fever-range whole-body hyperthermia on immunological markers in patients undergoing colorectal cancer surgery. Br J Anaesth 2012;109:754-61.

20. Ostberg JR, Gellin C, Patel R, Repasky EA. Regulatory potential of fever-range whole body hyperthermia on Langerhans cells and lymphocytes in an antigen-dependent cellular immune response. $J$ Immunol 2001;167:2666-70.

21. Banchereau J, Briere F, Caux C, Davoust J, Lebecque S, Liu YJ, Pulendran B, Palucka K. Immunobiology of dendritic cells. Annu Rev Immunol 2000;18:767-811.

22. Steinman RM. The dendritic cell system and its role in immunogenicity. Annu Rev Immunol 1991;9:271-96.

23. Förster R, Schubel A, Breitfeld D, Kremmer E, Renner-Müller I, Wolf E, Lipp M. CCR7 coordinates the primary immune response by establishing functional microenvironments in secondary lymphoid organs. Cell 1999;99:23-33.

24. Banchereau J, Steinman RM. Dendritic cells and the control of immunity. Nature 1998;392:245-52.

25. Gunn MD, Tangemann K, Tam C, Cyster JG, Rosen SD, Williams LT. A chemokine expressed in lymphoid high endothelial venules promotes the adhesion and chemotaxis of naive T lymphocytes. Proc Natl Acad Sci U S A 1998;95:258-63.

26. Ngo VN, Korner H, Gunn MD, Schmidt KN, Riminton DS, Cooper MD, Browning JL, Sedgwick JD, Cyster JG. Lymphotoxin alpha/beta and tumor necrosis factor are required for stromal cell expression of homing chemokines in B and $\mathrm{T}$ cell areas of the spleen. $J$ Exp Med 1999; 189:403-12.

27. Luther SA, Tang HL, Hyman PL, Farr AG, Cyster JG. Coexpression of the chemokines ELC and SLC by T zone stromal cells and deletion of the ELC gene in the plt/plt mouse. Proc Natl Acad Sci U S A 2000;97:12694-9.
28. Yoshida R, Nagira M, Kitaura M, Imagawa N, Imai T, Yoshie O. Secondary lymphoid-tissue chemokine is a functional ligand for the CC chemokine receptor CCR7. J Biol Chem 1998;273:7118-22.

29. Sallusto F, Mackay CR, Lanzavecchia A. The role of chemokine receptors in primary, effector, and memory immune responses. Annu Rev Immunol 2000;18:593-620.

30. Stein JV, Rot A, Luo Y, Narasimhaswamy M, Nakano H, Gunn MD, Matsuzawa A, Quackenbush EJ, Dorf ME, von Andrian UH. The CC chemokine thymus-derived chemotactic agent 4 (TCA-4, secondary lymphoid tissue chemokine, 6Ckine, exodus-2) triggers lymphocyte function-associated antigen 1-mediated arrest of rolling T lymphocytes in peripheral lymph node high endothelial venules. $J$ Exp Med 2000;191:61-76.

31. Tangemann K, Gunn MD, Giblin P, Rosen SD. A high endothelial cell-derived chemokine induces rapid, efficient, and subset-selective arrest of rolling $\mathrm{T}$ lymphocytes on a reconstituted endothelial substrate. J Immunol 1998;161:6330-7.

32. Bossi G, Griffiths GM. CTL secretory lysosomes: biogenesis and secretion of a harmful organelle. Semin Immunol 2005; 17:87-94.

33. de Saint Basile G, Ménasché G, Fischer A. Molecular mechanisms of biogenesis and exocytosis of cytotoxic granules. Nat Rev Immunol 2010;10:568-79.

34. Anel A, Buferne M, Boyer C, Schmitt-Verhulst AM, Golstein P. T cell receptor-induced Fas ligand expression in cytotoxic $\mathrm{T}$ lymphocyte clones is blocked by protein tyrosine kinase inhibitors and cyclosporin A. Eur J Immunol 1994;24:2469-76.

35. Gooden MJ, de Bock GH, Leffers N, Daemen T, Nijman HW. The prognostic influence of tumour-infiltrating lymphocytes in cancer: a systematic review with meta-analysis. Br J Cancer 2011;105:93-103.

36. Topalian SL, Hodi FS, Brahmer JR, Gettinger SN, Smith DC, McDermott DF, Powderly JD, Carvajal RD, Sosman JA, Atkins MB, Leming PD, Spigel DR, Antonia SJ, Horn L, Drake CG, Pardoll DM, Chen L, Sharfman WH, Anders RA, Taube JM, McMiller TL, Xu H, Korman AJ, Jure-Kunkel M, Agrawal S, McDonald D, Kollia GD, Gupta A, Wigginton JM, Sznol M. Safety, activity, and immune correlates of anti-PD-1 antibody in cancer. $N$ Engl $\mathrm{J} \mathrm{Med}$ 2012;366:2443-54.

37. Brahmer JR, Drake CG, Wollner I, Powderly JD, Picus J, Sharfman WH, Stankevich E, Pons A, Salay TM, McMiller TL, Gilson MM, Wang C, Selby M, Taube JM, Anders R, Chen L, Korman AJ, Pardoll DM, Lowy I, Topalian SL. Phase I study of single-agent antiprogrammed death-1 (MDX-1106) in refractory solid tumors: safety, clinical activity, pharmacodynamics, and immunologic correlates. $J$ Clin Oncol 2010;28:3167-75.

38. Zhang HG, Mehta K, Cohen P, Guha C. Hyperthermia on immune regulation: a temperature's story. Cancer Lett 2008;271:191-204.

39. Chen Q, Fisher DT, Clancy KA, Gauguet JM, Wang WC, Unger E, Rose-John S, von Andrian UH, Baumann H, Evans SS. Feverrange thermal stress promotes lymphocyte trafficking across high endothelial venules via an interleukin 6 trans-signaling mechanism. Nat Immunol 2006;7:1299-308.

40. Vardam TD, Zhou L, Appenheimer MM, Chen Q, Wang WC, Baumann H, Evans SS. Regulation of a lymphocyte-endothelialIL-6 trans-signaling axis by fever-range thermal stress: hot spot of immune surveillance. Cytokine 2007;39:84-96.

41. Ostberg JR, Kabingu E, Repasky EA. Thermal regulation of dendritic cell activation and migration from skin explants. Int $J$ Hyperthermia 2003;19:520-33

42. Kobayashi Y, Ito Y, Ostapenko VV, Sakai M, Matsushita N, Imai K, Shimizu K, Aruga A, Tanigawa K. Fever-range whole-body heat treatment stimulates antigen-specific T-cell responses in humans. Immunol Lett 2014;162:256-61.

43. Mace TA, Zhong L, Kilpatrick C, Zynda E, Lee CT, Capitano M, 
Minderman H, Repasky EA. Differentiation of CD8+ T cells into effector cells is enhanced by physiological range hyperthermia. $J$ Leukoc Biol 2011;90:951-62.

44. Minamiya Y, Saito H, Takahashi N, Ito M, Toda H, Ono T, Konno H, Motoyama S, Ogawa J. Expression of the chemokine receptor CCR6 correlates with a favorable prognosis in patients with adenocarcinoma of the lung. Tumour Biol 2011;32:197-202.

45. Grakoui A, Bromley SK, Sumen C, Davis MM, Shaw AS, Allen PM, Dustin ML. The immunological synapse: a molecular machine controlling T cell activation. Science 1999;285:221-7.

46. Monks CR, Freiberg BA, Kupfer H, Sciaky N, Kupfer A. Threedimensional segregation of supramolecular activation clusters in $\mathrm{T}$ cells. Nature 1998;395:82-6.

47. Ostberg JR, Kaplan KC, Repasky EA. Induction of stress proteins in a panel of mouse tissues by fever-range whole body hyperthermia. Int J Hyperthermia 2002;18:552-62.

48. Tsan MF, Gao B. Heat shock proteins and immune system. J Leukoc Biol 2009;85:905-10.

49. Srivastava PK, Udono H, Blachere NE, Li Z. Heat shock proteins transfer peptides during antigen processing and CTL priming. Immunogenetics 1994;39:93-8.

50. Binder RJ, Srivastava PK. Peptides chaperoned by heat-shock proteins are a necessary and sufficient source of antigen in the crosspriming of CD8+ T cells. Nat Immunol 2005;6:593-9.

51. Breloer M, Dorner B, Moré SH, Roderian T, Fleischer B, von Bonin A. Heat shock proteins as "danger signals": eukaryotic Hsp60 enhances and accelerates antigen-specific IFN-gamma production in T cells. Eur J Immunol 2001;31:2051-9.

52. Ramp U, Mahotka C, Heikaus S, Shibata T, Grimm MO, Willers R, Gabbert HE. Expression of heat shock protein 70 in renal cell carcinoma and its relation to tumor progression and prognosis. Histol Histopathol 2007;22:1099-107.

53. Mashaghi A, Bezrukavnikov S, Minde DP, Wentink AS, Kityk R, Zachmann-Brand B, Mayer MP, Kramer G, Bukau B, Tans SJ. Alternative modes of client binding enable functional plasticity of Hsp70. Nature 2016;539:448-51.

54. Wang Y, Gao B, Tsan MF. Induction of cytokines by heat shock proteins and concanavalin $\mathrm{A}$ in murine splenocytes. Cytokine 2005;32:149-54.

55. Terunuma H, Deng X, Dewan Z, Fujimoto S, Yamamoto N. Potential role of NK cells in the induction of immune responses: implications for NK cell-based immunotherapy for cancers and viral infections. Int Rev Immunol 2008;27:93-110.

56. Pandha H, Rigg A, John J, Lemoine N. Loss of expression of antigenpresenting molecules in human pancreatic cancer and pancreatic cancer cell lines. Clin Exp Immunol 2007;148:127-35.

57. Koopman LA, Corver WE, van der Slik AR, Giphart MJ, Fleuren GJ. Multiple genetic alterations cause frequent and heterogeneous human histocompatibility leukocyte antigen class I loss in cervical cancer. $J$ Exp Med 2000;191:961-76.

58. Madjd Z, Spendlove I, Pinder SE, Ellis IO, Durrant LG. Total loss of MHC class I is an independent indicator of good prognosis in breast cancer. Int J Cancer 2005;117:248-55.

59. Kitamura H, Torigoe T, Asanuma H, Honma I, Sato N, Tsukamoto T. Down-regulation of HLA class I antigens in prostate cancer tissues and up-regulation by histone deacetylase inhibition. J Urol 2007;178:692-6.

60. Djajadiningrat RS, Horenblas S, Heideman DA, Sanders J, de Jong J, Jordanova ES. Classic and nonclassic HLA class I expression in penile cancer and relation to HPV status and clinical outcome. J Urol 2015;193:1245-51.

61. Cheng M, Chen Y, Xiao W, Sun R, Tian Z. NK cell-based immunotherapy for malignant diseases. Cell Mol Immunol
2013;10:230-52.

62. Screpanti V, Wallin RP, Grandien A, Ljunggren HG. Impact of FASLinduced apoptosis in the elimination of tumor cells by NK cells. Mol Immunol 2005;42:495-9.

63. Takeda K, Hayakawa Y, Smyth MJ, Kayagaki N, Yamaguchi N, Kakuta S, Iwakura Y, Yagita H, Okumura K. Involvement of tumor necrosis factor-related apoptosis-inducing ligand in surveillance of tumor metastasis by liver natural killer cells. Nat Med 2001;7:94-100.

64. Dayanc BE, Beachy SH, Ostberg JR, Repasky EA. Dissecting the role of hyperthermia in natural killer cell mediated anti-tumor responses. Int $J$ Hyperthermia 2008;24:41-56.

65. Ostberg JR, Dayanc BE, Yuan M, Oflazoglu E, Repasky EA. Enhancement of natural killer (NK) cell cytotoxicity by fever-range thermal stress is dependent on NKG2D function and is associated with plasma membrane NKG2D clustering and increased expression of MICA on target cells. J Leukoc Biol 2007;82:1322-31.

66. Terunuma H, Deng X, Toki A, Yoshimura A, Nishino N, Takano Y, MIE Nieda M, Sasanuma J, Teranishi Y, Watanabe K. Effects of hyperthermia on the host immune system: from NK cell-based science to clinical application. Thermal Med 2012;28:1-9.

67. Bettelli E, Carrier Y, Gao W, Korn T, Strom TB, Oukka M, Weiner HL, Kuchroo VK. Reciprocal developmental pathways for the generation of pathogenic effector $\mathrm{TH} 17$ and regulatory $\mathrm{T}$ cells. Nature 2006;441:235-8.

68. Smyth MJ, Teng MW, Swann J, Kyparissoudis K, Godfrey DI, Hayakawa Y. CD4+CD25+ T regulatory cells suppress NK cellmediated immunotherapy of cancer. J Immunol 2006;176:1582-7.

69. Sakaguchi S, Wing K, Onishi Y, Prieto-Martin P, Yamaguchi T. Regulatory T cells: how do they suppress immune responses? Int Immunol 2009;21:1105-11.

70. Oleinika K, Nibbs RJ, Graham GJ, Fraser AR. Suppression, subversion and escape: the role of regulatory $\mathrm{T}$ cells in cancer progression. Clin Exp Immunol 2013;171:36-45.

71. Curiel TJ. Tregs and rethinking cancer immunotherapy. J Clin Invest 2007;117:1167-74.

72. Terunuma H, Wada A, Deng X, Yasuma Y, Onishi T, Toki A, Abe H. Mild hyperthermia modulates the relative frequency of lymphocyte cell subpopulations: an increase in a cytolytic NK cell subset and a decrease in a regulatory T cell subset. Thermal Med 2007;23:41-7.

73. Guo J, Zhu J, Sheng X, Wang X, Qu L, Han Y, Liu Y, Zhang H, Huo L, Zhang S, Lin B, Yang Z. Intratumoral injection of dendritic cells in combination with local hyperthermia induces systemic antitumor effect in patients with advanced melanoma. Int $J$ Cancer 2007;120:2418-25.

74. Terunuma H. Potentiating immune system by hyperthermia. In: Kokura S, Yoshikawa T, Ohnishi T, editors. Hyperthermic oncology from bench to bedside. Singapore: Springer Singapore; 2016. p. $127-$ 35 .

75. Hatzfeld-Charbonnier AS, Lasek A, Castera L, Gosset P, Velu T, Formstecher P, Mortier L, Marchetti P. Influence of heat stress on human monocyte-derived dendritic cell functions with immunotherapeutic potential for antitumor vaccines. J Leukoc Biol 2007;81:1179-87.

76. TanigawaK, ItoY, KobayashiY. Effects of fever-range hyperthermia on t cell-mediated immunity: possible combination of hyperthermia and $t$ cell-based cancer immunotherapy. Available from: https://link. springer.com/chapter/10.1007/978-981-10-0719-4_31\#citeas. [Last accessed on 19 Oct 2017]

77. Mallory M, Gogineni E, Jones GC, Greer L, Simone CB 2nd. Therapeutic hyperthermia: The old, the new, and the upcoming. Crit Rev Oncol Hematol 2016;97:56-64.

78. Jorritsma JB, Burgman P, Kampinga HH, Konings AW. DNA polymerase activity in heat killing and hyperthermic radiosensitization of mammalian cells as observed after fractionated heat treatments. 
Radiat Res 1986;105:307-19.

79. Weichselbaum RR, Dahlberg W, Little JB. Inherently radioresistant cells exist in some human tumors. Proc Natl Acad Sci USA 1985;82:4732-5.

80. Weichselbaum RR, Rotmensch J, Ahmed-Swan S, Beckett MA. Radiobiological characterization of 53 human tumor cell lines. Int $J$ Radiat Biol 1989;56:553-60.

81. Vaupel P. Tumor microenvironmental physiology and its implications for radiation oncology. Semin Radiat Oncol 2004;14:198-206.

82. Masunaga S, Nagata K, Suzuki M, Kashino G, Kinashi Y, Ono K. Inhibition of repair of radiation-induced damage by mild temperature hyperthermia, referring to the effect on quiescent cell populations. Radiat Med 2007;25:417-25.

83. Jorritsma JB, Kampinga HH, Scaf AH, Konings AW. Strand break repair, DNA polymerase activity and heat radiosensitization in thermotolerant cells. Int J Hyperthermia 1985;1:131-45.

84. Devun F, Biau J, Huerre M, Croset A, Sun JS, Denys A, Dutreix M. Colorectal cancer metastasis: the DNA repair inhibitor Dbait increases sensitivity to hyperthermia and improves efficacy of radiofrequency ablation. Radiology 2014;270:736-46.

85. Ohguri T, Imada H, Korogi Y, Narisada H. Clinical results of systemic chemotherapy combined with regional hyperthermia. Thermal Med 2007;23:49-61.

86. Hettinga JV, Konings AW, Kampinga HH. Reduction of cellular cisplatin resistance by hyperthermia--a review. Int J Hyperthermia 1997;13:439-57.

87. Da Silva VF, Feeley M, Raaphorst GP. Hyperthermic potentiation of BCNU toxicity in BCNU-resistant human glioma cells. J Neurooncol 1991;11:37-41.

88. Correale P, Del Vecchio MT, La Placa M, Montagnani F, Di Genova G, Savellini GG, Terrosi C, Mannucci S, Giorgi G, Francini G, Cusi MG. Chemotherapeutic drugs may be used to enhance the killing efficacy of human tumor antigen peptide-specific CTLs. $J$ Immunother 2008;31:132-47.

89. Sugarbaker PH, Stuart OA, Vidal-Jove J, Pessagno AM, DeBruijn EA. Pharmacokinetics of the peritoneal-plasma barrier after systemic mitomycin C administration. Cancer Treat Res 1996;82:41-52.

90. Los G, van Vugt MJ, Pinedo HM. Response of peritoneal solid tumours after intraperitoneal chemohyperthermia treatment with cisplatin or carboplatin. Br J Cancer 1994;69:235-41.

91. Yonemura Y, Canbay E, Li Y, Coccolini F, Glehen O, Sugarbaker PH, Morris D, Moran B, Gonzaletz-Moreno S, Deraco M, Piso P, Elias D, Batlett D, Ishibashi H, Mizumoto A, Verwaal V, Mahtem H. A comprehensive treatment for peritoneal metastases from gastric cancer with curative intent. Eur J Surg Oncol 2016;42:1123-31.

92. Fujishima Y, Goi T, Kimura Y, Hirono Y, Katayama K, Yamaguchi A. MUC2 protein expression status is useful in assessing the effects of hyperthermic intraperitoneal chemotherapy for peritoneal dissemination of colon cancer. Int J Oncol 2012;40:960-4.

93. Cravioto-Villanueva A, Cavazos M, Luna-Perez P, Martinez-Gomez H, Ramirez ML, Solorzano J, Montiel H, Esquivel J. Cytoreductive surgery with hyperthermic intraperitoneal chemotherapy (HIPEC) delivered via a modified perfusion system for peritoneal carcinomatosis of colorectal origin. Surg Today 2016;46:979-84.

94. Cummins KA, Russell GB, Votanopoulos KI, Shen P, Stewart JH, Levine EA. Peritoneal dissemination from high-grade appendiceal cancer treated with cytoreductive surgery (CRS) and hyperthermic intraperitoneal chemotherapy (HIPEC). J Gastrointest Oncol 2016;7:3-9.

95. Sugarbaker PH. Peritoneal metastases from adrenal cortical carcinoma treated by cytoreductive surgery and hyperthermic intraperitoneal chemotherapy. Tumori 2016;102:588-92.

96. Gnanamony M, Gondi CS. Chemoresistance in pancreatic cancer: Emerging concepts. Oncol Lett 2017;13:2507-13.
97. Boland CR, Goel A. Microsatellite instability in colorectal cancer. Gastroenterology 2010;138:2073-87.

98. Ribic CM, Sargent DJ, Moore MJ, Thibodeau SN, French AJ, Goldberg RM, Hamilton SR, Laurent-Puig P, Gryfe R, Shepherd LE, Tu D, Redston M, Gallinger S. Tumor microsatellite-instability status as a predictor of benefit from fluorouracil-based adjuvant chemotherapy for colon cancer. $N$ Engl J Med 2003;349:247-57.

99. Bonadonna G, Valagussa P. Dose-response effect of adjuvant chemotherapy in breast cancer. N Engl J Med 1981;304:10-5.

100. Shimizu K, Kotera Y, Aruga A, Takeshita N, Takasaki K, Yamamoto M. Clinical utilization of postoperative dendritic cell vaccine plus activated T-cell transfer in patients with intrahepatic cholangiocarcinoma. J Hepatobiliary Pancreat Sci 2012;19:171-8.

101. Sjoquist KM, Burmeister BH, Smithers BM, Zalcberg JR, Simes RJ, Barbour A, Gebski V; Australasian Gastro-Intestinal Trials Group. Survival after neoadjuvant chemotherapy or chemoradiotherapy for resectable oesophageal carcinoma: an updated meta-analysis. Lancet Oncol 2011;12:681-92.

102. Du D, Liu Y, Qian H, Zhang B, Tang X, Zhang T, Liu W. The effects of the CCR6/CCL20 biological axis on the invasion and metastasis of hepatocellular carcinoma. Int J Mol Sci 2014;15:6441-52.

103. Klevebro F, Johnsen G, Johnson E, Viste A, Myrnäs T, Szabo E, Jacobsen AB, Friesland S, Tsai JA, Persson S, Lindblad M, Lundell L, Nilsson M. Morbidity and mortality after surgery for cancer of the oesophagus and gastro-oesophageal junction: a randomized clinical trial of neoadjuvant chemotherapy vs. neoadjuvant chemoradiation. Eur J Surg Oncol 2015;41:920-6.

104. Stahl M, Walz MK, Stuschke M, Lehmann N, Meyer HJ, RieraKnorrenschild J, Langer P, Engenhart-Cabillic R, Bitzer M, Königsrainer A, Budach W, Wilke H. Phase III comparison of preoperative chemotherapy compared with chemoradiotherapy in patients with locally advanced adenocarcinoma of the esophagogastric junction. J Clin Oncol 2009;27:851-6.

105. Kitamura K, Kuwano H, Watanabe M, Nozoe T, Yasuda M, Sumiyoshi K, Saku M, Sugimachi K. Prospective randomized study of hyperthermia combined with chemoradiotherapy for esophageal carcinoma. J Surg Oncol 1995;60:55-8.

106. Issels RD, Lindner LH, Verweij J, Wust P, Reichardt P, Schem BC Abdel-Rahman S, Daugaard S, Salat C, Wendtner CM, Vujaskovic Z, Wessalowski R, Jauch KW, Dürr HR, Ploner F, Baur-Melnyk A, Mansmann U, Hiddemann W, Blay JY, Hohenberger P; European Organisation for Research and Treatment of Cancer Soft Tissue and Bone Sarcoma Group (EORTC-STBSG); European Society for Hyperthermic Oncology (ESHO). Neo-adjuvant chemotherapy alone or with regional hyperthermia for localised high-risk soft-tissue sarcoma: a randomised phase 3 multicentre study. Lancet Oncol 2010;11:561-70.

107. Kimura F, Shimizu H, Yoshidome H, Ohtsuka M, Miyazaki M. Immunosuppression following surgical and traumatic injury. Surg Today 2010;40:793-808.

108. Sacerdote P, Bianchi M, Gaspani L, Manfredi B, Maucione A, Terno G, Ammatuna M, Panerai AE. The effects of tramadol and morphine on immune responses and pain after surgery in cancer patients. Anesth Analg 2000;90:1411-4.

109. Tsuchiya Y, Sawada S, Yoshioka I, Ohashi Y, Matsuo M, Harimaya Y, Tsukada K, Saiki I. Increased surgical stress promotes tumor metastasis. Surgery 2003;133:547-55.

110. van der Zee J. Heating the patient: a promising approach? Ann Oncol 2002;13:1173-84

111. Feldmann HJ, Seegenschmiedt MH, Molls M. Hyperthermia--its actual role in radiation oncology. Part III: Clinical rationale and results in deep seated tumors. Strahlenther Onkol 1995;171:251-64.

112. Haveman J, Van Der Zee J, Wondergem J, Hoogeveen JF, Hulshof MC. Effects of hyperthermia on the peripheral nervous system: a review. Int J Hyperthermia 2004;20:371-91. 